\title{
SWI5 wt Allele
}

National Cancer Institute

\section{Source}

National Cancer Institute. SWI5 wt Allele. NCI Thesaurus. Code C101633.

Human SWI5 wild-type allele is located in the vicinity of 9q34.11 and is approximately 14 $\mathrm{kb}$ in length. This allele, which encodes DNA repair protein SWI5 homolog protein, plays a role in the modulation of DNA repair. 